Agropedology 2016, 26 (01), 29-33

\title{
Economics of Kharif Sorghum Production in Southern Dry Zone of Karnataka
}

\author{
S.C. Ramesh Kumar ${ }^{1 *}$, A.B. Tejaswini ${ }^{2}$, M.K. Prakashanaik ${ }^{2}$, \\ S. Nandini', Rajendra Hedge ${ }^{3}$ and S. K. Singh ${ }^{4}$
}

\author{
ICAR - National Bureau of Soil Survey and Land use Planning, \\ Regional Center, Hebbal, Bangalore-560024 \\ ${ }^{4}$ NBSS\&LUP, Nagpur -440033, Maharashtra
}

\begin{abstract}
The decline in food grain production in general and sorghum cultivation in particular is a major concern for policy makers and planners. The study presents trends in sorghum production, economic viability, possibilities for bridging the yield gap in sorghum cultivation using primary data in Chamarajanagara district representing southern dry zone of Karnataka. Sorghum, a major dry land crop of Karnataka, showed negative growth rate in production (-0.4\%) which is mainly due to decline in area $(-3.8 \%)$. Decomposition analysis reveals that area effect is higher for change in production of sorghum. Economic viability of sorghum showed that net returns were relatively higher among small farmers (Rs. 7264 per ha) followed by medium farmers (Rs 4503 per ha) and large farmers (Rs 1681 per ha). There is scope for enhancing present sorghum yield by 66 to $70 \%$ among the farmers. To bridge this gap, the use of recommended levels of input and in particular fertilizer most essential. Path coefficient analysis indicated significant correlation of yield gap with $\mathrm{N}$ and $\mathrm{P}$ gaps. Variation in rainfall, and soil fertility problems are the major constraints faced by farmers. Sorghum is severely damaged by wild pig in which results in wide variability in the incomes of the farmer.
\end{abstract}

Keywords: Growth rate, Yield Gap, Economic Assessment, Sorghum, rainfed

\section{Introduction}

Sorghum is an important cereal and staple diet of resource poor people in Karnataka. The Government launched ambitious programme called Anna Bhagya Yojana to supply a certain quantity of food grains at free of cost to priority household families below poverty line across the State. A total of 108.98 lakh priority households are eligible to receive free food grains through a network of 20,778 fair price shops across the State from May 2015. Karnataka government is encouraging farmers for growing sorghum by providing incentives through minimum support prices. (Government of Karnataka. 2014). Sorghum is being produced mainly by marginal and small farmers whose production system are generally characterized by the use of traditional method. Sorghum is the major rainfed crop in the area which is taken during kharif season. The major constraints faced by farmers in the area are variation in rainfall, followed by soil problems like low fertility,

*Corresponding Author Email: scrameshkumar@gmail.com crusting, presence of gravels, sloping lands and crop loss due to wild animals. In addition, there is no adequate information on the economics of sorghum production in the area, especially the profitability status and efficiency of resource use in sorghum production. It is therefore important to study the cost and return of sorghum production and scale economics of resource used by the farmers with the aim of improving the enterprise and farmers' productivity for an increased food production in the state. This study attempts an economic analysis of sorghum production in Chamarajanagar district in southern dry zone of Karnataka. It focused on socio-economic characteristic of the farmers, profitability, resource use efficiency and problem of sorghum production in the area.

\section{Material and Methods}

The study covers both macro and micro aspects of sorghum cultivation. To know the changing scenario of sorghum production in the area as well as state and the country secondary data on area, production and yield of 
sorghum in Chamarajanagar, Karnataka and India were collected from published reports. Primary data were collected in Hosahalli micro-watershed of chamarajanagar district of Karnataka during March 2015. The primary data on cost of inputs and resource use pattern was collected from 43 sample farmers in the area. Among these, twenty one are small farmers ( $<1 \mathrm{ha})$, eleven each one medium (1-2 ha) and large ( $>2$ ha) farmers.

Compound growth rates were estimated with the following exponential model.

$\mathrm{Y}=\mathrm{ab}{ }^{\mathrm{t}, \mathrm{CGR}}(\mathrm{r})=(\mathrm{b}-1) * 100$, the ' $\mathrm{t}$ ' test was applied to test the significance of ' $b$ '

To measure the relative contribution of area and yield to the total output change for Sorghum, component analysis model as cultivated by Minhas and Vidhyanathan (1964) was used. Sharma (1977) modified the model and several research workers used this model and studied growth performance of crops on state level (Narulu and Vidysagar 1973; Bastine and Palanisami 1994; Bhatnagar and Nandal 1994; Mundinamani et al. 1995; Gupta and Saraswat 1997 and Siju and Kombairaju, 2001). $\mathrm{r}_{\mathrm{yi}}=\mathrm{r}_{1 \mathrm{i}} \mathrm{P}_{\mathrm{y} 1}+\mathrm{r}_{2 \mathrm{i}} \mathrm{P}_{\mathrm{y} 2}+\mathrm{r}_{3 \mathrm{i}} \mathrm{P}_{\mathrm{y} 3}+\ldots \ldots+\mathrm{r}_{\mathrm{ni}} \mathrm{P}_{\mathrm{yn}}$

Where, $\mathrm{i}=(1$ to 5$)$ is the correlated cause and ' $\mathrm{y}$ ' is the effect

$$
P_{y i}=b_{i} \frac{\sigma_{i}}{\sigma_{y}}
$$

These direct and indirect effects of independent variable included in path analysis were obtained by constructing correlation coefficient (rji) matrix, flow chart of the direct and indirect effects and $\mathrm{R}^{2} \%$ matrices.

\section{Results and Discussion}

The sorghum area in India was more than 10 million ha in 1999 and has gradually decreased to 6.21 million ha in 2012-13 (Table 1). Karnataka was the second largest sorghum producer (production 1.3 MT, area of $1.26 \mathrm{M}$ ha, productivity $10.4 \mathrm{qha}^{-1}$ during 2012-13) in India.

Table 1. Area, Production and Yield of Sorghum (1999-00 to 2012-13)

\begin{tabular}{|c|c|c|c|}
\hline Items & Units & $1999-2000$ & $2012-2013$ \\
\hline \multicolumn{4}{|c|}{ Chamarajanagar } \\
\hline Area & ('000 ha) & 25.9 & 21.4 \\
\hline Production & ('000 tones) & 14.5 & 8.7 \\
\hline $\begin{array}{l}\text { Yield } \\
\text { Karnataka }\end{array}$ & $\left(\mathrm{qha}^{-1}\right)$ & 5.6 & 4.1 \\
\hline Area & ('000 ha) & 2024 & 1263 \\
\hline Production & ('000 tones) & 1791 & 1315 \\
\hline $\begin{array}{l}\text { Yield } \\
\text { India }\end{array}$ & $\left(\mathrm{q} \mathrm{ha} \mathrm{C}^{-1}\right)$ & 8.8 & 10.4 \\
\hline Area & ('000 ha) & 10250 & 6210 \\
\hline Production & ('000 tones) & 8680 & 5280 \\
\hline Yield & $\left(\mathrm{qha}^{-1}\right)$ & 8.47 & 8.5 \\
\hline
\end{tabular}

Source: Directorate of Economics and Statistics, Government of India and Karnataka (1999 to 2013)

The area and production of sorghum in the country showed negative growth rate and yield showed positive growth rate. Though at macro level, yield of sorghum showed positive growth rate, the actual yields obtained are considerably lower than those recorded in the demonstration plots and research stations/farms. Chamarajanagar district is 
one of the sorghum growing district of Karnataka having production of 8700 tonnes with an area of 21400 ha and productivity of $4.1 \mathrm{q} \mathrm{ha}^{-1}$ during 2012-13. The growth rates of area, production and productivity of sorghum in the district and the country are presented in Table 2 . The area under sorghum in this district showed negative and significant growth rate whereas production and yield showed positive and non significant growth. In Karnataka and India growth in area and production is negative and yield growth rate is positive and significant, which indicates reason for decline in sorghum production in the country and Karnataka.

Table 2. Compound annual growth rates (CAGR) and coefficient of variation (CV) of Area, Production and Yield of Sorghum (1999-2000 to 2012-2013)

\begin{tabular}{lccc}
\hline Study area & Particulars & CAGR (\%) & CV (\%) \\
\hline Chamarajanagar & Area & $-1.9^{*}$ & 16.3 \\
& Production & 0.1 & 54.0 \\
\multirow{3}{*}{ Karnataka } & Yield & 2.0 & 42.7 \\
& Area & $-3.8^{* * *}$ & 16.9 \\
& Production & $-0.4^{\mathrm{NS}}$ & 18.9 \\
India & Yield & $3.1^{* *}$ & 22.0 \\
& Area & $-3.6^{* * *}$ & 15.4 \\
& Production & $-2.0^{* * *}$ & 11.5 \\
& Yield & $1.7^{* * *}$ & 10.6 \\
\hline
\end{tabular}

***Denotes significance at 0.01 level of significance ** Denotes significance at 0.05 level of significance * Denotes significance at 0.1 level of significance

The coefficient of variation for all the three variables i.e. area, production and yield has was higher in the Chamarajanagar district compared to state and the country. The coefficient of variation is higher in case of production.

The output growth for sorghum can be attributed to three effects i.e., yield effect, area effect, and interaction effect. The relative contribution of yield, area and their interaction to changes in production of sorghum is presented in Table 3. In all the cases the area effect is higher for change in production of sorghum.

Table 3. Contribution of changes in area, yield and production (1999-2000 to 2012-2013) of Sorghum (\%)

\begin{tabular}{lccc}
\hline Study area & Yield effect & Area effect & Interaction effect \\
\hline Chamarajanagar & -3478.2 & 3018.2 & 560.0 \\
Karnataka & -166.7 & 213.3 & 53.4 \\
India & -81.6 & 157.5 & 24.1 \\
\hline
\end{tabular}

Cost and returns from sorghum cultivation by different size group farmers is presented in Table 4 . The total cost of sorghum cultivation in area ranged between Rs.13671 ha $^{-1}$ in case of small farmers (with labour cost $68 \%$, input cost of $32 \%$ and the net income and benefit cost ratio (BCR) of Rs.7264 ha ${ }^{-1}$ and 1.153 respectively) and Rs.14908 ha ${ }^{-1}$ in case of large farmers (with labour cost of $71 \%$, input cost of
$29 \%$ and the net income and BCR of Rs 1681 ha and 1.11 respectively). Basavaraja et al. (2005) found that the per hectare cost of cultivation was Rs.10345 in Dharwad district and Rs.7536 in Belgaum district. Negative profitability of small farmers from sorghum cultivation may be attributed to higher labour and input cost associated with lower yield under rain fed conditions. 
Table 4. Economics of sorghum production in Chamarajanagar district of Karnataka

\begin{tabular}{lccc}
\hline \multicolumn{1}{c}{ Particulars } & Small farmers & Medium farmers & Large farmers \\
\hline Labour cost $\left(\mathrm{Rs.} \mathrm{ha}^{-1}\right)$ & $9288(68 \%)$ & $9725(69 \%)$ & $10537(71 \%)$ \\
Input cost $\left(\mathrm{Rs}^{-1} \mathrm{ha}^{-1}\right)$ & $4383(32 \%)$ & $4288(31 \%)$ & $4372(29 \%)$ \\
Total Cost $\left(\mathrm{Rs} \mathrm{ha}^{-1}\right)$ & 13671 & 14014 & 14908 \\
Yield $\left(\mathrm{Qty} \mathrm{ha}{ }^{-1}\right)$ & 6.00 & 5.56 & 5.27 \\
Gross Returns $\left(\mathrm{Rs} \mathrm{ha}^{-1}\right)$ & 20935 & 18517 & 16589 \\
Net returns $\left(\mathrm{Rs} \mathrm{ha}^{-1}\right)$ & 7264 & 4503 & 1681 \\
B:C Ratio & 1.53 & 1.32 & 1.11 \\
\hline
\end{tabular}

Nitrogen consumption per hectare of sorghum cultivation is highest in case of large farmers. Phosphorus and potassium consumption is highest in case of small farmers. Small farmers obtained higher yield of sorghum (6 $\left.\mathrm{q} \mathrm{ha}^{-1}\right)$ and there is marginal variation in yield obtained by medium (5.56 $\left.\mathrm{qha}^{-1}\right)$ and large farmers $\left(5.27 \mathrm{q} \mathrm{ha}^{-1}\right)$.

Details on levels of input (FYM and NPK) used by farmers, actual yield obtained, recommended level of inputs and potential yield of sorghum in different size groups is presented in Table 5. The difference between potential yield (package of practice) and the yield obtained by farmers is considered as the yield gap. The difference between input

Table 5. Adoption and yield gap in sorghum cultivation

\begin{tabular}{|c|c|c|c|}
\hline Particulars & Small farmers & Medium farmers & Large farmers \\
\hline \multicolumn{4}{|l|}{ A. Farmers' Practices } \\
\hline Seed $\left(\mathrm{kgha}^{-1}\right)$ & 25.9 & 39.0 & 20.5 \\
\hline FYM $\left(\mathrm{t} \mathrm{ha}^{-1}\right)$ & 2.2 & 1.6 & 1.9 \\
\hline Nitrogen $\left(\mathrm{kgha}^{-1}\right)$ & 46.6 & 40.4 & 68.3 \\
\hline Phosphorus $\left(\mathrm{kgha}^{-1}\right)$ & 27.3 & 13.9 & 22.1 \\
\hline Potash $\left(\mathrm{kgha}^{-1}\right)$ & 11.2 & 4.6 & 6.7 \\
\hline $\operatorname{Yield}\left(\mathrm{qha}^{-1}\right)$ & 6.00 & 5.56 & 5.27 \\
\hline \multicolumn{4}{|c|}{ B. POP Recommendations } \\
\hline Seed $\left(\mathrm{kgha}^{-1}\right)$ & 7.5 & 7.5 & 7.5 \\
\hline FYM $\left(t \mathrm{ha}^{-1}\right)$ & 5.0 & 5.0 & 5.0 \\
\hline Nitrogen $\left(\mathrm{kgha}^{-1}\right)$ & 65.0 & 65.0 & 65.0 \\
\hline Phosphorus $\left(\mathrm{kgha}^{-1}\right)$ & 40.0 & 40.0 & 40.0 \\
\hline Potash $\left(\mathrm{kgha}^{-1}\right)$ & 40.0 & 40.0 & 40.0 \\
\hline Potential Yield (q ha $\left.{ }^{-1}\right)$ & 18.0 & 18.0 & 18.0 \\
\hline \multicolumn{4}{|c|}{ C. Adoption/Yield Gap (B-A) } \\
\hline Seed $\left(\mathrm{kgha}^{-1}\right)$ & -18.4 & -31.5 & -13.0 \\
\hline FYM $\left(t \mathrm{ha}^{-1}\right)$ & 2.8 & 3.4 & 3.1 \\
\hline Nitrogen $\left(\mathrm{kgha}^{-1}\right)$ & 18.4 & 24.6 & -3.3 \\
\hline Phosphorus $\left(\mathrm{kgha}^{-1}\right)$ & 12.7 & 26.1 & 17.9 \\
\hline Potash $\left(\mathrm{kgha}^{-1}\right)$ & 28.8 & 35.4 & 33.3 \\
\hline Yield gap $\left(\mathrm{q} \mathrm{ha}^{-1}\right)$ & 12.0 & 12.44 & 12.73 \\
\hline
\end{tabular}

recommendation according to package of practices and quantity of inputs used by the farmers is considered as adoption gap. Small farmers used seed, FYM and NPK fertilizer to the tune of $25.9 \mathrm{~kg} \mathrm{ha}{ }^{-1}, 2.2 \mathrm{t} \mathrm{ha}^{-1}$ and 46.6:27.3:11.2 $\mathrm{kg} \mathrm{ha}^{-1}$ respectively and the yield obtained was $6 \mathrm{q} \mathrm{ha}^{-1}$. The package of practices recommendation to achieve potential yield of $18 \mathrm{q} \mathrm{ha}^{-1}$ is $7.5 \mathrm{~kg} \mathrm{ha}^{-1}$ (seed), $5 \mathrm{t} \mathrm{ha}^{-1}$ (FYM) and 65:40:40 $\mathrm{kg} \mathrm{ha}^{-1}$ (NPK). Farmers apply less quantity of FYM (2.8 $\left.\mathrm{tha}^{-1}\right), \mathrm{N}\left(18.4 \mathrm{~kg} \mathrm{ha}^{-1}\right), \mathrm{P}\left(12.7 \mathrm{~kg} \mathrm{ha}^{-1}\right)$ and $\mathrm{K}\left(28.8 \mathrm{~kg} \mathrm{ha}^{-1}\right)$. Farmers' yield $\left(6 \mathrm{q} \mathrm{ha}^{-1}\right)$ were lower as compared to recommended level (18 $\left.\mathrm{q} \mathrm{ha}^{-1}\right)$. Similar pattern medium and large farmers. of adoption/yield gap can be seen in sorghum grown by 
The direct and indirect effects of input-use gaps are presented in Table 6. The yield gap is the result of gap in quantity of inputs used and composite variable that included other factors affecting yield gap. The unexplained residual variance not accounted by four explanatory variables worked out to be $0.85 \%$. The summation of direct and indirect effects gives the correlation coefficient between the variables. The direct effect of FYM gap and $\mathrm{N}$ gap on yield gap is higher than their indirect effects. $\mathrm{K}$ gap has negative direct effect on yield gap of sorghum. A significant positive correlation between yield gap and $\mathrm{N}$ gap and yield gap and $\mathrm{P}$ gap implies positive effect of application of $\mathrm{N}$ and $\mathrm{P}$ on yield.

Table 6. Table of path coefficients for sorghum yield

\begin{tabular}{lccccc}
\hline & $\mathbf{F Y M}\left(\mathbf{X}_{\mathbf{1}}\right)$ & $\mathbf{N}\left(\mathbf{X}_{\mathbf{2}}\right)$ & $\mathbf{P}\left(\mathbf{X}_{\mathbf{3}}\right)$ & $\mathbf{K}\left(\mathbf{X}_{\mathbf{4}}\right)$ & $\mathbf{r}$ \\
\hline $\mathbf{F Y M}\left(\mathbf{X}_{\mathbf{1}}\right)$ & $\mathbf{0 . 1 6}$ & 0.00 & 0.02 & -0.04 & 0.14 \\
$\mathbf{N}\left(\mathbf{X}_{\mathbf{2}}\right)$ & $\mathbf{( 1 1 3 . 2 3 )}$ & $(-1.25)$ & $(15.21)$ & $(-27.19)$ & $(100)$ \\
& 0.00 & $\mathbf{0 . 3 7}$ & 0.06 & -0.08 & $0.34^{* *}$ \\
$\mathbf{P}\left(\mathbf{X}_{\mathbf{3}}\right)$ & $(-0.22)$ & $\mathbf{( 1 0 7 . 0 7 )}$ & $(17.39)$ & $(-24.24)$ & $(100)$ \\
& 0.04 & 0.26 & $\mathbf{0 . 0 9}$ & -0.11 & $0.27^{*}$ \\
$\mathbf{K}\left(\mathbf{X}_{\mathbf{4}}\right)$ & $(14.78)$ & $(95.57)$ & $\mathbf{( 3 1 . 2 1 )}$ & $(-41.56)$ & $(100)$ \\
& 0.04 & 0.21 & 0.06 & $\mathbf{- 0 . 1 5}$ & 0.17 \\
& $(24.87)$ & $(125.33)$ & $(39.11)$ & $\mathbf{( - 8 9 . 3 1 )}$ & $(100)$ \\
\hline
\end{tabular}

\section{Residual effect : 0.85}

Note: Figures in parentheses indicates \% to total effect $* *$ denotes significance at 0.05 level of significance

* denotes significance at 0.1 level of significance

\section{Conclusions}

The study used time series data for the period 1999 to 2012 to examine the growth of sorghum in Karnataka. The results revealed that sorghum cultivation area is showing a declining trend and reduction of $3.6 \%$ in India, 3.8\% in Karnataka and $1.9 \%$ in Chamarajanagar district. Farm household data on economic viability of sorghum showed that net returns were relatively high among small farmers (Rs.7264) followed by medium farmers (Rs. 4503) and large farmers (Rs. 1681). There is scope for enhancing present sorghum yield by 66 to $70 \%$.

\section{References}

Basavaraja, H., Hugar, A.Y., Mahajanashetti, S.B., Angadi, V.V and Dayakar Rao, B. (2005) Kharif Sorghum in Karnataka: An Economic Analysis. Agricultural Economics Research Review 18, 223-240.

Bastine, C.L. and Palanisami K.P.. (1994) An Analysis of Growth Trends in Principal Crops in Kerala. Agricultural Situation in India, 48 (12), 885-891.

Bhatnagar, S. and Nandal, D.S. (1994) Growth in wheat in Haryana. Agricultural Situation in India, 49, 75-78. Gupta, B.S. and Saraswat, P.K. (1997) Growth of Rapeseed and Mustard in Western Rajasthan. Agriculture Situation in India, 54, 449-466.

Minhas, B.S. and Vidhyanathan, A.(1964) Growth of crop output in India, 1951-54 to 1958-61-Analysis by component elements. Journal of The Indian Society of Agricultural Statistics 28, 230-252.

Mundinamani, S.M., Sastry, K.N.R. And Murthy, T.N.V. (1995) Growth Performance of Oilseeds in Karnataka, Agricultural Situation in India, 50 (7):451-456.

Narula, S. and Vidyasagar, S. (1973) Methodology of Working out Contribution of Area and Yield in Increasing Production, Agricultural Situation in India 27, 473-477.

Sharma, K.L. (1977) Measurement of the Effects of Area, Yield and Prices in the Increase of Value of Crop Output in India. Agricultural Situation in India 32, 349-351.

Siju, T. and Kombairaju, S. (2001) Rice Production in Tamil Nadu: A Trend and Decomposition Analysis. Agricultural Situation in India 58, 143-145.

Received : March, 2016

Accepted : May, 2016 